\title{
PERBANDINGAN BUSANA ARCA HARIHARA ERA KLASIK AKHIR (KOLEKSI HERMITAGE MUSEUM ST.PETERSBURG, MUSEUM NASIONAL JAKARTA, DAN BALAI LELANG CHRISTIE'S)
}

\author{
Waridah Muthi'ah ${ }^{1} \&$ Agus Sachari ${ }^{2}$ \\ ${ }^{1}$ Program Studi Ilmu Seni Rupa dan Desain, Sekolah Pasca Sarjana Fakultas Seni Rupa dan Desain, Institut Teknologi Bandung \\ ${ }^{1}$ Program Studi Desain Produk, Fakultas Seni Rupa dan Desain, Institut Teknologi Bandung \\ waridah.muthiah@students.itb.ac.id
}

Received 9 February 2021; accepted 28 June 2021; published 30 July 2021

\begin{abstract}
Harihara is the amalgamation of two great gods in Hinduism: Siva and Vishnu. During the Late Classical Era (Majapahit period, 13th-15th centuries AD) three deification statues which portrayed the kings as Harihara have been found. Out of these three, two of them are not located in Indonesia anymore, one is part of the collection of Hermitage Museum, St. Petersburg, and one is in Christie's Auction Gallery. Since these statues are not widely known, they are barely mentioned or studied in the field of classical archaeology and art. This research focuses on the physical attributes of those statues, particularly the clothing elements and divine attributes, in comparation to the deification statue of Raden Wijaya as Harihara, which is originated from Candi Simping and now is located in National Museum, Jakarta. The research was conducted using a qualitativecomparative method with iconographic and historical approach. It is found that while these statues show the amalgamation of Siva and Vishnu's attributes, the depiction of Harihara in those statues are not exactly following Harihara iconography as regulated in the canons of Silpasastra Manasara. While the canon portrays physical attributes of Shiva and Vishnu side by side equally, in the depiction of Harihara in Java, those attributes are mixed and not always follows a rigid pattern. It is suggested that the depiction of kings as Harihara show an attempt to project them as the unifier of different factions and religious sects. The inequal depiction of Vishnu and Siva's attributes in king's deification statues indicates not only the dynamics of the religion in the era, but also as mean to build king's image in the image of the aforementioned God.
\end{abstract}

KEYWORDS

clothing,

comparative study, Harihara,

Majapahit, statues

This is an open access article under the CC-BY-SA license

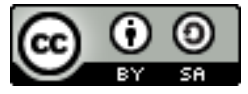

\section{Pengantar}

Amalgamasi atau penggabungan dua dewa dalam satu tubuh merupakan sebuah fenomena yang banyak ditemui dalam tradisi Hindu. Pada arca, kedua dewa digambarkan sebagai setengah belahan tubuh yang sama, ditandai dengan simbol-simbol yang menjadi atribut keduanya. Contohnya adalah Harihara (Syiwa-Wisnu), Ardhanariswari (Syiwa-Parwati), dan Brahmanarayana (Brahma-Wisnu).

Berdasarkan temuan candi dan arca, kepercayaan yang berkembang di Nusantara adalah Siwaisme dan Buddhisme. Akan tetapi, di samping kedua agama tersebut, ditemukan pula buktibukti pemujaan kepada Wisnu dan Harihara, khususnya dalam bentuk arca. Arca Harihara yang telah ditemukan sejauh ini antara lain adalah arca Harihara Batang (era Praklasik) (Indradjaja dan Degroot 2018), arca Harihara Dieng (era Klasik Awal) (Balai Pelestarian Cagar Budaya Jawa Tengah 2016), arca Harihara Kediri (era Klasik Tengah), arca Harihara Kembar dari Jawa Timur, serta arca Harihara Simping (era Klasik Akhir) (Direktorat Perlindungan Kebudayaan 2018).

Dikarenakan latar belakang historis penemuan dan perdagangan benda-benda cagar budaya sebelum era kemerdekaan, saat ini beberapa artefak era klasik berada di luar Indonesia. Di antaranya 
adalah arca Harihara yang menjadi koleksi Hermitage Museum, St. Petersburg; serta arca Harihara dalam katalog Balai Lelang Christie's dengan nomor lot 702. Dilihat dari langgam penggambaran, disinyalir bahwa kedua arca ini berasal dari akhir masa Singasari hingga era Majapahit, yakni antara akhir abad ke-13 hingga abad ke-15. Melihat kurun waktu tersebut, arca ini sezaman dengan arca Harihara dari Candi Simping, yang saat ini menjadi koleksi Museum Nasional Indonesia.

Dilihat dari ciri khusus seperti gestur, ekspresi, serta kelengkapan busana, ketiga arca tersebut merupakan arca perwujudan (deification statue), yakni arca yang menggambarkan seseorang yang sudah meninggal (postmortem/dead portrait statue) dalam wujud dewa yang dipujanya (istadewata) (Putra, Redig, dan Aryana 2018). Arca jenis ini dicirikan dengan sikap tubuh berdiri kaku dan mata tertutup, serta mengenakan busana megah dilengkapi atribut kedewaan (Suantika 2013). Sikap kaku ini menunjukkan sikap meditatif sebagai persatuan sang raja dengan dewa (Deshpande 2016).

Jika arca Harihara Simping diyakini sebagai arca perwujudan Raden Wijaya, raja Majapahit pertama, arca Harihara koleksi Hermitage Museum yang menunjukkan ciri-ciri gaya seni yang lebih tua disinyalir merupakan perwujudan Kertanegara, raja Singasari terakhir (Pullen 2021). Tokoh raja yang diwujudkan pada arca Harihara Balai Lelang Christie's belum dapat diidentifikasi, tetapi berdasarkan ciri ragam hias, arca ini berlanggam Majapahit Tengah, yakni sekitar abad ke-14.

Fenomena arca perwujudan pada Era Klasik Akhir dilatarbelakangi oleh konsep dewaraja yang menempatkan seorang penguasa sebagai representasi dewa di muka bumi (Sudrajat 2012). Konsep ini dapat dihubungkan dengan konsep raja ideal, yang terkait dengan konsep Chakravarti dan Rajamandala yang berkembang di India (Rahardjo 2011). Meski arca perwujudan banyak ditemukan pada era Klasik Akhir (abad ke-13 hingga 16), praktik ini berakar dari kepercayaan Megalitikum, yakni pembuatan menhir atau patung peringatan sebagai media komunikasi dengan arwah leluhur.

Dalam arca pendharmaan, pemilihan sosok dewa untuk merepresentasikan raja dilatarbelakangi oleh agama atau kepercayaan yang dianut sang raja. Menimbang hal tersebut, pemilihan Harihara menjadi menarik, mengingat Harihara bukan sekte utama yang berkembang saat itu. Terlebih, adanya dua arca Harihara selain arca Harihara Simping menegaskan fakta bahwa pemilihan sosok Harihara untuk merepresentasikan raja bukanlah sebuah fenomena yang terjadi pada arca Raden Wijaya saja.

Keberadaan arca-arca tersebut menjadi fenomena yang menarik dalam pembahasan mengenai ikonografi klasik era Hindu-Buddha di Indonesia, karena meskipun menggambarkan tokoh yang sama dan berasal dari kurun waktu yang sama, kedua arca tersebut memiliki beberapa kekhasan yang membedakannya dengan arca-arca Harihara lain yang ada di Indonesia. Perbedaan yang jelas terlihat adalah dari jenis atribut, kelengkapan busana dan perhiasan, serta langgam gaya seni. Tulisan ini berupaya memperbandingkan atribut fisik arca Harihara koleksi St. Petersburg, Balai Lelang Christie, dan arca Harihara Simping, khususnya segi busana, serta mengaitkannya dengan aspek historis yang melatarbelakangi penggambaran tersebut. Diharapkan tulisan ini dapat memberi sumbangsih dalam pembahasan mengenai langgam seni dan busana pada arca Majapahit.

\section{Pembahasan}

\subsection{Arca Harihara Ardhanari, The State Hermitage Museum, St. Petersburg, Rusia}

Arca Harihara Ardhanari (Gambar 1a) setinggi 1,45 meter ini merupakan koleksi Hermitage State Museum, St. Petersburg, dengan nomor inventaris NQ BD-543. Arca ini adalah arca perwujudan Kertanegara, raja terakhir Singasari. Ciri Singasari diperlihatkan oleh ciri ukiran teratai yang keluar dari bonggolnya pada stela di sisi kanan tokoh. Mengingat bahwa Kertanegara meninggal pada saat kejatuhan Singasari, disimpulkan bahwa upacara sraddha dan pembuatan arca perwujudan dilangsungkan pada era Majapahit, yakni pada pemerintahan Raden Wijaya.

Keberadaan arca ini disinggung dalam kitab Desawarnana (Negarakertagama), Pupuh 55: 3 dan 56: 1-2 yang menyebutkan mengenai arca Siwa dan Buddha Aksobya di Candi Sang Batara yang didirikan oleh Sri Kertanegara dan terletak di kaki Gunung Kemukus, Jajawa. Pupuh 43:3 juga menyebutkan mengenai mangkatnya Raja Kertanegara dan pembangunan candi dengan arca Siwa dan Buddha sebagai makam sang raja (Saktiani 2016: 146-147, 181-184). Candi Jajawa tersebut 
disimpulkan sebagai Candi Jawi di kaki Gunung Welirang (Santiko 2020: 31). Akan tetapi, saat ini kedua arca tersebut sudah tidak ada lagi di Candi Jawi. Pada Pupuh 57: 3-4, disebutkan bahwa sejak 1331 M., arca Aksobya tersebut sudah hilang (Saktiani 2016: 186-187). Arca yang dipercaya sebagai Aksobya ditemukan di Surabaya, oleh masyarakat setempat dikenal sebagai arca Joko Dolog (Santiko 2020: 32). Hal ini mengindikasikan bahwa saat itu, arca Siwa masih terdapat di tempat. Tulisan Stutterheim pada 1932 menyebutkan bahwa pada 1861, arca Siwa yang terdapat di candi tersebut dibawa oleh Jerman dari sumber Belanda ke Museum fur Volkerkunde, Berlin, lantas dibawa oleh Rusia ke Leningrad (sekarang St. Petersburg) pada sekitar 1945-1946, untuk ditempatkan di gudang State Hermitage Museum (Pullen 2021: 203-204). Arca ini sempat dipamerkan pada musim semi 2016, dimuat dalam katalog patung Asia Tenggara koleksi museum ini (Deshpande 2016: 125, 389), serta diulas dalam buku Patterned Splendour karya Lesley S. Pullen (2021: 203-207).

Bentuk dada arca ini memperlihatkan wujud setengah perempuan dan setengah laki-laki (Ardhanari). Jika biasanya arca Ardhanari menampilkan Syiwa dan Parwati, laksana yang hadir pada arca ini adalah atribut Syiwa dan Wisnu. Syiwa Sang Perusak digambarkan sebagai sisi maskulin, sedangkan Wisnu Sang Pemelihara sebagai sisi feminin. Ketersandingan dua sifat yang bertentangan dalam satu tubuh, yakni Syiwa/Wisnu, maskulin/feminin, perusak/pemelihara, adalah representasi dualisme oposisi biner yang saling melengkapi (dwi-tunggal). Dengan demikian, Harihara Ardhanari adalah representasi dua kekuatan yang seimbang dan selaras sebagai pembentuk kehidupan.

Pada ikonografi India, Harihara digambarkan dengan pembagian simetris yakni sisi kanan untuk Syiwa dan sisi kiri untuk Wisnu. Namun, pada arca ini tidak terlihat pola tersebut. Walaupun posisi sisi laki-laki dan perempuan menuruti kaidah ikonografi Ardhanari India, pola penempatan laksana ditampilkan bersilangan. Di sisi kanan, terdapat kerang bersayap (sankha) sedangkan di tangan kiri terdapat tasbih dan gada. Sayangnya, tangan kanan depan sudah rusak, sehingga tidak terlihat laksana yang dipakai. Sankha dan gada adalah laksana Wisnu, sedangkan tasbih merupakan laksana Syiwa.

Pembagian simetris bersebelahan itu juga tidak terlihat dari segi busana. Jika menurut kanon, arca Harihara digambarkan dengan tatanan rambut jatamakuta pada sisi kanan (Syiwa) dan kiritamakuta pada sisi kiri (Wisnu), pada arca ini hanya ditemukan satu jenis mahkota yakni jatamakuta. Hal ini ditandai oleh gelung spiral pada bagian tengah mahkota yang menandakan pilinan rambut. Pada pakaian dan perhiasan yang dikenakan, tidak terdapat atribut dewa tertentu.

Arca ini mengenakan cita sepanjang mata kaki bermotif ceplok bunga kelopak empat berseling motif susunan lingkaran dalam garis kotak-kotak. Sebagai pelengkap, digunakan sepasang selendang yang membelit pinggang dan menjulur hingga mata kaki. Selendang yang menjuntai di depan dan sisi tubuh berlipit vertikal dan memiliki ujung berbentuk V seperti ekor burung layang-layang. Perhiasan yang dikenakan berupa sepasang anting panjang, kalung lebar bertumpuk, kelat bahu, gelang (kankana), tali kasta (yajnopavita) yang menjulur di sisi kiri tubuh dan bersatu dengan hiasan panggul yang menjuntai hingga lutut (pattika), hiasan panggul dengan hiasan simbar belah ketupat, sepasang uncal, dan gelang kaki. Hal yang unik dari pemakaian uncal yang tidak terdapat pada arca lain adalah bagian tengah uncal membelit pattika secara longgar, sebelum terulur menjuntai.

\subsection{Arca Harihara Simping, Museum Nasional Jakarta}

Arca Harihara yang ditemukan di Candi Simping, Blitar (Gambar 1b) merupakan perwujudan Raden Wijaya (Kertarajasa Jayawardhana), pendiri Majapahit. Bukti mengenai hal tersebut tercantum dalam Kitab Desawarnana (Negara Kertagama) yang menyebutkan mengenai percandian untuk raja pertama Majapahit tersebut di Simping. Arca setinggi 1,60 meter ini sekarang menjadi koleksi Museum Nasional Indonesia, Jakarta, dengan nomor inventaris 103a/256.

Pada arca ini, Harihara ditampilkan dalam posisi berdiri dan bertangan empat. Laksana berupa sankha (cangkang kerang) di tangan kanan belakang, aksamala (tasbih) di tangan kanan depan, vajra (lidah api) di tangan kiri belakang, serta gada di tangan kiri depan. Dua sosok berukuran setengah tinggi tokoh mengapit di sisi kanan dan kiri. Hiasan bunga teratai yang menempel pada stela (latar batu) tampak di belakang kedua sosok tersebut. Pada bagian belakang kepala terdapat siraschakra bentuk bulat telur, dihiasi dua lembar pita menjulur. Kendati tidak diragukan lagi bahwa arca ini 
berasal dari era Majapahit, pada arca ini, tidak terdapat hiasan garis-garis sinar sentripetal Surya Majapahit. kepala yang menjadi ciri khas arca era tersebut.

Pakaian tokoh terdiri atas kain panjang (cita) semata kaki yang dilengkapi dengan dua pasang selendang (sampur) di sisi kanan dan kiri tubuh, yang disimpul di panggul. Kedua ujung selendang terlihat bertumpuk, dengan salah satu sisi lebih pendek dari yang lain. Hal yang menarik dari arca ini adalah keberadaan motif kawung yang menghiasi kain. Dari kehalusan ukiran motif, diasumsikan bahwa motif ini dibuat dengan teknik non-tenun, yang kemungkinan adalah batik. Mahkota yang dikenakan berjenis kiritamakuta, yakni mahkota berbentuk kerucut terpotong, dihiasi dengan deretan lima simbar pada tiara (jamang) yang melingkari kepala. Melengkapinya, dikenakan perhiasan anting panjang (kundala), kalung bersusun dua (hara), kelat bahu (keyura), gelang (kankana), hiasan panggul, serta sepasang hiasan menjuntai di depan paha (uncal).

\subsection{Arca Harihara Balai Lelang Christie's}

Arca Harihara milik Balai Lelang Christie's (Gambar 1c) terdaftar dengan nomor Lot 702. Keterangan yang terdapat di laman situs tersebut menyebutkan bahwa pemilik sebelumnya adalah seorang diplomat yang pernah bekerja di Indonesia pada 1963-1971, yang mengindikasikan bahwa arca ini sempat berpindah dari tangan ke tangan. Akan tetapi, selain keterangan bahwa arca ini berasal dari Jawa Timur, tidak disebutkan asal daerah penemuan arca maupun identitas raja secara mendetail. Melihat ciri pijar-pijar garis sentripetal yang berpusat pada kepala arca, siraschakra bentuk nisan dengan hiasan dua pita, serta hiasan tanaman teratai yang keluar dari guci, bisa disimpulkan bahwa arca ini berasal dari era Majapahit Tengah, yakni dari sekitar abad ke-14.

Arca ini menampilkan sosok dewa bertangan empat dalam posisi berdiri. Meskipun keterangan pada laman web Christie's Auction and Private Sales (Christie's 2003) menyebutkan arca ini sebagai arca Wisnu, tetapi dilihat dari laksana, bisa disimpulkan bahwa tokoh yang digambarkan adalah Harihara. Identifikasi sosok tersebut sebagai Harihara dilihat dari tangan kanan arca yang memegang lingkaran cakra, sementara tangan kiri memegang kebutan lalat (camara). Cakra adalah senjata Wisnu, sedangkan camara adalah laksana Syiwa. Pada bagian atas cakra terlihat bentuk ulir yang mengesankan api atau asap, sehingga cakra ini adalah cakra api (flaming cakra). Wajah arca ini terlihat tenang dengan mata tertutup, yang menunjukkan bahwa arca ini adalah arca perwujudan, namun tokoh yang diwujudkan belum diketahui. Dari segi busana, sosok ini mengenakan busana raya yang terdiri atas cita (kain) panjang dengan selendang dan perhiasan megah. Di bagian belakang mahkota kiritamakuta terdapat siraschakra berbentuk nisan dengan hiasan dua lembar pita rambut.
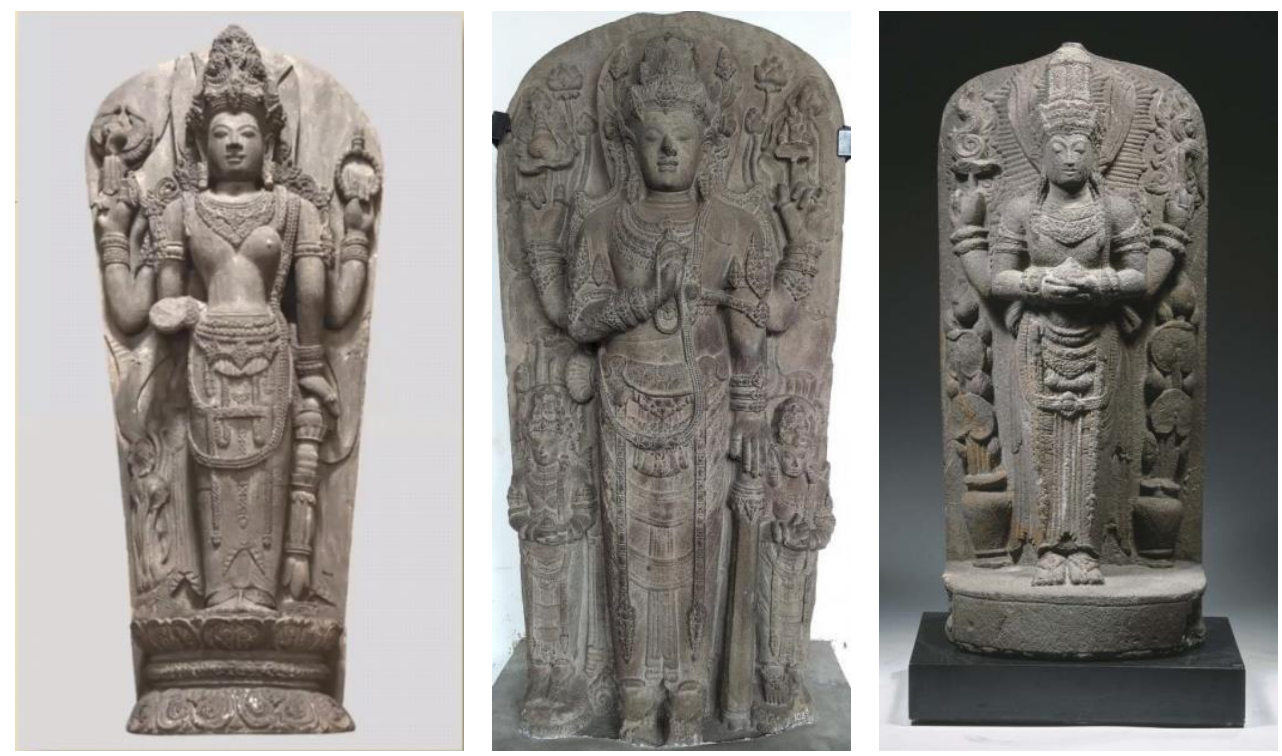

Gambar 1. a) Arca Harihara milik Balai Lelang Christie's (Foto: Christie's 2003); b) Arca Harihara Simping (Foto: Museum Nasional Indonesia 2019); c) Arca Harihara Jajawi, Hermitage State Museum (Pullen 2021) 
Gelar: Jurnal Seni Budaya

Vol 19, No 1 (2021)

ISSN 1410-9700 (print) | 2655-9153 (online)

https://jurnal.isi-ska.ac.id/index.php/gelar

\subsection{Perbandingan Busana Arca Harihara}

Tabel 1. Unsur Busana pada Arca Harihara Era Klasik Akhir

\begin{tabular}{|c|c|c|c|}
\hline Unsur Busana & Hermitage State Museum & Simping (Museum Nasional) & Balai Lelang Christie's \\
\hline Mahkota & Jatamakutha & Kiritamakutha & Kiritamakutha \\
\hline $\begin{array}{l}\text { Anting } \\
\text { (kundala) }\end{array}$ & $\begin{array}{l}\text { Anting panjang berbentuk } \\
\text { kerang (sankhakundala), } \\
\text { menjuntai menyentuh bahu }\end{array}$ & $\begin{array}{l}\text { Anting panjang bentuk kerang } \\
\text { dengan hiasan daun (sankha- } \\
\text { patrakundala), menyentuh bahu. }\end{array}$ & $\begin{array}{l}\text { Anting panjang, menjuntai } \\
\text { melewati bahu, motif susunan } \\
\text { bunga/daun (patrakundala) }\end{array}$ \\
\hline $\begin{array}{l}\text { Kelat bahu } \\
\text { (keyura) }\end{array}$ & $\begin{array}{l}1 \text { tumpuk, tebal dengan simbar. } \\
\text { Hiasan deretan lingkaran di } \\
\text { bagian tengah, diapit dua garis }\end{array}$ & $\begin{array}{l}2 \text { tumpuk. Lapis atas dihiasi } 3 \\
\text { simbar, simbar tengah berukuran } \\
\text { besar. Lapis bawah berbentuk V }\end{array}$ & 2 tumpuk dengan simbar \\
\hline Kalung (hara) & $\begin{array}{l}2 \text { tumpuk, bentuk kurva pipih } \\
\text { dan tebal }\end{array}$ & $\begin{array}{l}5 \text { tumpuk (vaijayanti), motif } \\
\text { besar di tengah. Kalung untai } \\
\text { manik-manik pada deret bawah }\end{array}$ & $\begin{array}{l}2 \text { tumpuk, bentuk kurva pipih } \\
\text { dan tebal, bagian depan } \\
\text { berbentuk kaku (segilima) }\end{array}$ \\
\hline $\begin{array}{l}\text { Gelang } \\
\text { (kankana) }\end{array}$ & $\begin{array}{l}2 \text { tumpuk, ukuran besar, tanpa } \\
\text { simbar. Ukiran flora pada lapis } \\
\text { atas dan deretan lingkaran pada } \\
\text { lapis bawah }\end{array}$ & $\begin{array}{l}3 \text { tumpuk, ukuran besar. Gelang } \\
\text { lapis atas dihiasi simbar }\end{array}$ & $\begin{array}{l}2 \text { tumpuk, ukuran besar tanpa } \\
\text { simbar. Bentuk cembung di } \\
\text { bagian tengah (gelang balok) }\end{array}$ \\
\hline $\begin{array}{l}\text { Tali dada } \\
\text { (stana-sutra) }\end{array}$ & - & $\begin{array}{l}\text { Tali tebal melintang di bawah } \\
\text { dada, pada bagian bawah dihiasi } \\
\text { dengan untaian manik-manik }\end{array}$ & $\begin{array}{l}\text { Tidak terlihat (tertutup } \\
\text { tangan) }\end{array}$ \\
\hline $\begin{array}{l}\text { Tali kasta } \\
\text { (yajnopavita) }\end{array}$ & $\begin{array}{l}\text { Susunan manik-manik/mutiara } \\
\text { dari bahu kiri, menjuntai tegak } \\
\text { lurus di sisi tubuh, hiasan plat } \\
\text { persegi bermotif bunga di } \\
\text { tengahnya. Pada bahu terdapat } \\
\text { untaian pendek bersisik. }\end{array}$ & $\begin{array}{l}\text { Susunan manik-manik/mutiara } \\
\text { dari bahu kiri dan menjuntai } \\
\text { tegak lurus di dada, bersambung } \\
\text { dengan pattika. Di tengahnya } \\
\text { ada hiasan emblem dengan } \\
\text { permukaan menonjol }\end{array}$ & $\begin{array}{l}\text { Tebal dan penuh hiasan, } \\
\text { menjuntai tegak lurus di sisi } \\
\text { tubuh dan bersambung dengan } \\
\text { pattika. Bagian bawah kaku, } \\
\text { di tengahnya dihiasi bunga } \\
\text { kelopak empat (rosette) }\end{array}$ \\
\hline $\begin{array}{l}\text { Ikat pinggang } \\
\text { (udarabandha) }\end{array}$ & Bentuk seperti anyaman tali & $\begin{array}{l}\text { Simpul ikat pinggang di atas } \\
\text { uncal }\end{array}$ & $\begin{array}{l}\text { Ikat pinggang dengan simpul } \\
\text { di atas uncal. }\end{array}$ \\
\hline $\begin{array}{l}\text { Hiasan } \\
\text { panggul (kati- } \\
\text { bandha) }\end{array}$ & $\begin{array}{l}3 \text { susun, lapisan terbawah } \\
\text { dihiasi tiga simbar berbentuk } \\
\text { bunga kelopak empat. }\end{array}$ & 2 susun, berbentuk kurva & $\begin{array}{l}3 \text { susun, tebal. Bagian } \\
\text { terbawah berbentuk kurva, } \\
\text { bermotif bunga kelopak empat }\end{array}$ \\
\hline $\begin{array}{l}\text { Juntaian } \\
\text { hiasan di } \\
\text { depan paha } \\
\text { (uncal) }\end{array}$ & $\begin{array}{l}\text { Sepasang, motif susunan garis } \\
\text { diagonal, sangat panjang } \\
\text { hingga digantungkan pada } \\
\text { pattika, dengan bulatan } \\
\text { (bandul) di ujungnya. Terdapat } \\
\text { hiasan panjang di tengah kain }\end{array}$ & $\begin{array}{l}\text { Sepasang, lebar, bermotif seling- } \\
\text { seling antara bunga kelopak } \\
\text { empat dan susunan lingkaran. } \\
\text { Terdapat bentuk serupa mata } \\
\text { panah/simbar dengan hiasan } \\
\text { motif bunga di ujungnya. }\end{array}$ & $\begin{array}{l}\text { Sepasang, tebal dan bermotif. } \\
\text { Bagian ujungnya terdapat } \\
\text { bentuk serupa mata } \\
\text { panah/simbar dengan hiasan } \\
\text { motif bunga }\end{array}$ \\
\hline Kain (cita) & $\begin{array}{l}\text { Kain panjang semata kaki, wiru } \\
\text { di bagian tengah. Terdapat } \\
\text { garis draperi di bagian bawah }\end{array}$ & $\begin{array}{l}\text { Kain panjang semata kaki, tanpa } \\
\text { draperi, wiru di bagian tengah }\end{array}$ & $\begin{array}{l}\text { Kain panjang semata kaki, } \\
\text { tanpa draperi, wiru di bagian } \\
\text { tengah }\end{array}$ \\
\hline $\begin{array}{l}\text { Selendang } \\
\text { (sampur) }\end{array}$ & $\begin{array}{l}\text { Sepasang di kiri dan kanan } \\
\text { tubuh, berlipit, ujung bentuk V. } \\
\text { Ujung selendang sama panjang }\end{array}$ & $\begin{array}{l}\text { Sepasang di kiri dan kanan, } \\
\text { disimpul di pinggang Salah satu } \\
\text { ujung selendang lebih pendek }\end{array}$ & $\begin{array}{l}\text { Sepasang disimpul di } \\
\text { pinggang. Salah satu ujung } \\
\text { selendang lebih pendek }\end{array}$ \\
\hline Gelang kaki & Tidak terlihat (sudah rusak) & Tidak terlihat (sudah rusak) & Pipih, hiasan rosette \\
\hline
\end{tabular}

Tabel 1 menunjukkan bahwa walaupun secara garis besar, jenis elemen dan kelengkapan busana dari ketiga arca Harihara tersebut sama, terdapat perbedaan visualisasi elemen-elemen busana tersebut, khususnya dari segi bentuk dan ragam hias. 
Perbedaan yang mencolok adalah pada penggunaan mahkota. Jika kedua arca yang berasal dari era Majapahit mengenakan kiritamakuta, arca Kertanegara mengenakan jatamakuta. Hal ini dapat dihubungkan dengan perkembangan religi pada masa tersebut. Sebagaimana dibuktikan oleh bangunan keagamaan yang bersifat sinkretis, kehidupan keagamaan pada era Singasari ditandai oleh ketersandingan Hindu dan Buddha, dengan Siwaisme sebagai paham yang dominan (Santiko 2020). Dalam Negarakertagama Pupuh 55: 3 dan Pupuh 56: 1-2, disebutkan bahwa raja diwujudkan sebagai Siwa dan Buddha Aksobya. Walaupun penggambaran raja sebagai Harihara dapat dipandang sebagai upaya untuk merepresentasikan raja sebagai pemersatu dan penyeimbang dunia, arca ini memberi penekanan pada aspek Siwa, sehingga raja digambarkan dengan jatamakuta.

Penekanan aspek Siwa pada arca Harihara mengalami pergeseran pada masa Majapahit. Pada arca Simping dan Christie's, Harihara mengenakan kiritamakuta, yakni mahkota kerucut terpotong atau pot terbalik yang merupakan atribut Wisnu (Acharya 1995; Rao 1997). Bahkan pada era ini, kiritamakuta menggantikan mahkota lain seperti jatamakuta, karandamakuta, dan kesabandha.

Walaupun kiritamakuta adalah atribut penanda Wisnu, pada praktiknya di Indonesia, Wisnu tidak selalu digambarkan dengan mahkota tersebut. Pada era Tarumanegara, arca-arca Wisnu di Cibuaya ditampilkan dengan kiritamakuta. Akan tetapi, pada era Klasik Awal, Wisnu dan para avatarnya (Rama dan Kresna) mengenakan karandamakuta (mahkota berbentuk cangkang kerang), sebagaimana tampak pada arca dan relief di Kompleks Candi Prambanan. Kiritamakuta hadir kembali di Jawa Timur, tepatnya pada era Kediri dan Majapahit. Namun, tidak hanya menjadi atribut Wisnu, kiritamakuta juga menjadi mahkota raja, contohnya pada relief Kresnayana di Candi Induk Panataran, Blitar, serta Candi Jago, Malang. Penggunaan kiritamakuta sebagai mahkota raja berarti menyejajarkan peran Wisnu sebagai dewa pemelihara dunia dengan peran raja sebagai pemelihara kerajaan. Hal ini sesuai dengan prinsip kesejajaran makrokosmos dan mikorokosmos yang menjadi fondasi konsep dewaraja, sebagai landasan pemikiran utama di balik keberadaan arca perwujudan.

Hal yang menarik adalah terdapat penggambaran motif bunga kelopak empat yang berulang. Motif bunga kelopak empat ini hadir sebagai elemen ragam hias utama pada perhiasan gelang, kalung, emblem pada yajnopavita, serta uncal. Selain itu, hadir pula motif lingkaran yang dikelilingi oleh delapan lingkaran kecil, dengan empat lingkaran pada keempat sudutnya. Pada kain, hadir motif kawung, yang merupakan pengembangan repetitif tidak terhingga dari motif lingkaran dengan empat kelopak di dalamnya. Motif-motif tersebut memiliki kesamaan, yakni perulangan pola empat sebagai pengembangan pola sentripetal pada bidang lingkaran dengan satu titik sebagai pusatnya. Motif kawung/ceplok merupakan motif yang banyak terdapat pada arca dan relief dari masa Hindu-Buddha (Pullen 2021). Filosofi motif kawung sebagai simbol empat arah mata angin yang mengelilingi pusat bisa diartikan sebagai mandala sebagai simbol kekuasaan (Rosanto 2009; Riyanto 2019), serta dapat juga diterapkan pada dua motif lain. Motif ini merepresentasikan konsep macapat atau keblat papat lima pancer, yang dapat dihubungkan dengan pola Astamandala yang menggambarkan Dewata Nawasanga, yakni delapan dewa pelindung mata angin dalam tradisi Hindu Jawa dan Bali.
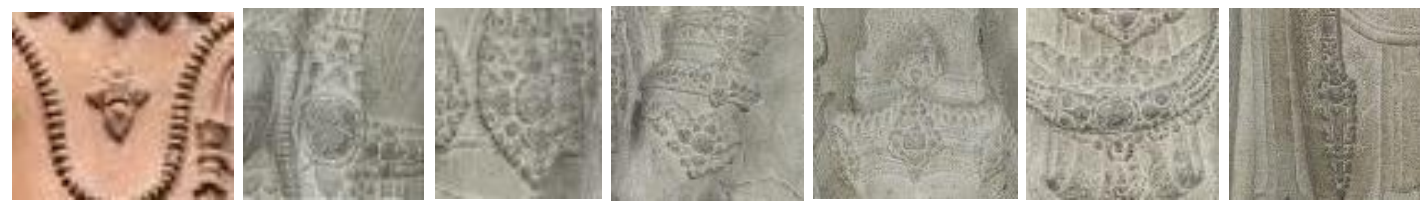

Gambar 2. Perbandingan antara penggambaran srivatsa pada arca Wisnu India (kiri) dan berbagai ragam hias mandala pada arca Harihara Simping (Foto: Museum of Fine Arts Boston 2018, dok. pribadi 2021)

Jika dihubungkan dengan tradisi Hindu, terdapat pola yang disebut srivatsa, yakni tanda berupa bunga atau simpul tak berujung yang tampak pada dada Wisnu. Seperti juga pola sentripetal yang muncul pada motif kawung, bunga kelopak empat, dan ceplok pada arca Harihara, pola ini juga mengetengahkan pola sentripetal dengan simpul atau kelopak di keempat sisinya. Pada motif bunga kelopak empat pada perhiasan, khususnya di emblem pada yajnopavita, mahkota, gelang, kalung, dan perhiasan panggul, pada bagian tengah terdapat tonjolan yang menyerupai batu permata. Bentuk ini menunjukkan kaustabhamani, yakni batu permata mirah delima yang dikenakan oleh Wisnu. 
Pola sentripetal ini merujuk pada pola mandala dalam tradisi Hindu. Dalam konsep mandala, raja ditempatkan di titik pusat sebagai pemegang kekuasaan, disejajarkan dengan dewa sebagai penguasa alam semesta (Lombard 2005; Rahardjo 2011; Munandar 2011). Pola ini tidak hanya terwujud dalam ragam hias dan arsitektur, tetapi juga tercermin dalam sistem kekuasaan dan pemerintahan (Bafna 2000; Dellios 2003). Penitikberatan aspek Wisnu pada penggambaran Harihara pada era Majapahit bertujuan untuk mencitrakan raja sebagai penguasa sekaligus pengayom dan pelindung kerajaan.

Seperti pada era Singasari, kehidupan keagamaan Majapahit juga diwarnai dengan kemajemukan agama, sehingga penggambaran raja sebagai Harihara dapat dipandang dari kerangka yang sama, yakni sebagai pemersatu dan penyeimbang. Dari perspektif politis, dengan adanya bukti arca Harihara sebagai perwujudan Kertanegara, perwujudan Raden Wijaya sebagai Harihara bisa dinilai sebagai upaya legitimasi untuk menunjukkan dirinya sebagai menantu Kertanegara dan penerus trah Singasari yang sah. Hal yang perlu digarisbawahi adalah fakta bahwa Majapahit berdiri setelah menjatuhkan Kediri, yang terlebih dahulu menjatuhkan Singasari. Penekanan status sebagai pewaris Singasari merupakan legitimasi genealogis bagi Majapahit untuk membentuk dan melangsungkan kekuasaannya, yang kemudian diperkuat dengan fondasi keagamaan melalui pencitraan ilahiah. Penekanan pada aspek Wisnu juga merupakan representasi analogis Raden Wijaya sebagai avatar Wisnu yang membasmi angkara murka dan mengembalikan keseimbangan dunia.

\section{Kesimpulan}

Dari hasil perbandingan terhadap tiga arca Harihara era Klasik Akhir yakni arca Harihara Simping koleksi Museum Nasional Jakarta, arca Harihara koleksi State Hermitage Museum St. Petersburg, serta arca Harihara koleksi Balai Lelang Christie's, disimpulkan bahwa walaupun secara garis besar memiliki persamaan, terdapat variasi detail pada penggambaran unsur-unsur pembentuk busana dan atribut kedewaan. Variasi busana terlihat pada detail elemen busana serta kelengkapan elemen busana,. Variasi tersebut khususnya terlihat pada penggambaran mahkota Harihara yang bergeser dari jatamakuta pada arca perwujudan Kertanegara (Singasari) menjadi kiritamakuta pada arca perwujudan raja-raja Majapahit. Selain itu, tampak pula variasi pada detail perhiasan (tali kasta, kelat bahu, kalung, gelang, hiasan panggul) dan ragam hias pada kain, yang kemungkinan besar berkaitan dengan perkembangan langgam seni pada era Majapahit.

Pada detail busana arca, terlihat pola yang berulang yakni ragam hias yang dikembangkan dari pola mandala (sentripetal). Selain berfungsi estetis, ragam hias ini memiliki keterkaitan dengan tokoh dewa yang digambarkan, yakni srivatsa, ragam hias bunga kelopak empat pada dada Wisnu. Jika dihubungkan dengan pola mandala, ragam hias ini memiliki makna menunjukkan kedudukan raja sebagai pusat kekuasaan, sebagai representasi kekuasaan dewa di muka bumi.

Perwujudan raja sebagai Harihara pada arca era Klasik Akhir dapat dipandang dalam perspektif politis dan keagamaan. Dari segi keagamaan, identitas dewa merepresentasikan kepercayaan yang dianut raja. Tetapi dari segi politis, hal ini memiliki makna yang lebih dalam. Dengan menimbang konsep dewaraja serta keseimbangan makrokosmos-mikrokosmos sebagai dasar pembentukan arca perwujudan, pemilihan sosok dewa dapat dilihat dari kacamata politis untuk menampilkan citra raja dalam sifat dewa yang bersangkutan. Perwujudan raja sebagai Harihara merupakan representasi citra raja sebagai penyeimbang dan pemersatu kerajaan dengan latar belakang yang majemuk.

\section{Kepustakaan}

Acharya, Prasanna Kumar. 1995. Architecture of Manasara: Illustrations of Architectural and Sculptural Objects, with A Synopsis, Manasara Series : Vol. V. New Delhi: Munshiram Manoharlal Publishers.

Bafna, Sonit. 2000. "On the Idea of the Mandala as a Governing Device in Indian Architectural Tradition." Journal of the Society of Architectural Historians 59 (1): 26-49. https://doi.org/https://doi.org/10.2307/991561.

Balai Pelestarian Cagar Budaya Jawa Tengah. 2016. "Hariharamurti.” Balai Pelestarian Cagar 
Budaya Jawa Tengah. February 23, 2016.

https://kebudayaan.kemdikbud.go.id/bpcbjateng/hariharamurti/.

Christie's. 2003. "A Fine East Javanese Andesite Figure of Vishnu." Asian Ceramics and Works of Art. 2003. https://www.christies.com/lot/lot-a-fine-east-javanese-andesite-figure-of-4089556/.

Dellios, Rosita. 2003. "Mandala : From Sacred Origins to Sovereign Affairs in Traditional

Southeast Asia." Centre for East-West Cultural and Economic Studies, 1-16.

Deshpande, Olga. 2016. Sculpture of Southeast Asia in The Hermitage. St. Petersburg: State Hermitage Publishing House.

Direktorat Perlindungan Kebudayaan. 2018. "Arca Harihara Koleksi Museum Nasional Indonesia Jakarta." Sistem Registrasi Nasional Cagar Budaya. 2018.

https://cagarbudaya.kemdikbud.go.id/public/objek/detailcb/PO2017080100008/arca-hariharakoleksi-museum-nasional-no-inv-256-103a-2082.

Indradjaja, Agustijanto, dan Véronique Degroot. 2018. "Early Traces Hindu-Buddhist Influence Along the North Coast of Central Java: Archaeological Survey of the District of Batang." Amerta 32 (1). https://doi.org/10.24832/amt.v32i1.375.

Lombard, Denys. 2005. Nusa Jawa: Silang Budaya Vol. 03 Warisan Kerajaan-Kerajaan Konsentris. Jakarta: Gramedia Pustaka Utama.

Munandar, Agus Aris. 2011. Catuspatha Arkeologi Majapahit. Wedatama W. Jakarta.

Museum Nasional Indonesia. 2019. “Arca Harihara.” Kementerian Pendidikan Dan Kebudayaan Direktorat Jenderal Kebudayaan. 2019. https://kebudayaan.kemdikbud.go.id/munas/arcaharihara/.

Museum of Fine Arts Boston. 2018. "Vishnu." Museum of Fine Arts, Boston. 2018. https://collections.mfa.org/objects/28948.

Pullen, Lesley S. 2021. Patterned Splendour: Textiles Presented on Javanese Metal and Stone Sculptures Eighth to Fifteenth Century. Singapore: ISEAS - Yushof Ishak Institute.

Putra, Putu Pradnyana Adi, I Wayan Redig, dan A. A. Gde Aryana. 2018. "Variasi Ikonografi Arca-Arca Perwujudan Perunggu Koleksi Museum Bali Dan BPCB Bali-Nusa Tenggara." Humanis 22: 41. https://doi.org/10.24843/jh.2018.v22.i01.p07.

Rahardjo, S. 2011. Peradaban Jawa: Dari Mataram Kuno Sampai Majapahit Akhir. Jakarta: Komunitas Bambu.

Rao, G. 1997. Elements of Hindu Iconography. New Delhi: Motilal Banarsida Pub.

Riyanto, Sugeng. 2019. "Ragam Hias pada Candi sebagai Motif Batik." Prosiding Seminar Nasional Industri Kerajinan Dan Batik 2019, A1_1-A1_17.

Rosanto, Anton. 2009. "Kajian Batik Motif Kawung dan Parang dengan Pendekatan Estetika Seni Nusantara." Kajian Batik Motif Kawng Dan Parang Dengan Pendekatan Estetika Seni Nusantara 1 (2): 1-11. https://jurnal.isi-ska.ac.id/index.php/brikolase/article/view/261/263.

Saktiani, Damaika. 2016. Kakawin Negarakertagama: Teks dan Terjemahan. Yogyakarta: Narasi.

Santiko, Hariani. 2020. “Kehidupan Beragama Raja Kertanagara.” Kalpataru 29 (1): 29-38. https://doi.org/10.24832/kpt.v29i1.634.

Suantika, I Wayan. 2013. “Arca Garuda Wisnu Di Pura Gelang Agung, Buangga, Getasan, Petang, Badung.” Forum Arkeologi 26 (1): 38-51.

Sudrajat. 2012. "Konsep Dewa Raja dalam Negara Tradisional Asia Tenggara." Prosiding Workshop Mengajar Dan Meneliti Asia Tenggara 1 (1). 